\title{
RAKSTI
}

\author{
S O C I O L O Ģ I J A
}

\section{Aleksandrs Ivanovs \\ THE IMPACT OF METAHISTORY ON ETHNIC IDENTITY: THE CASE OF THE LATVIAN DIASPORA IN THE SOVIET UNION IN THE 1920s-1930s}

DOI: https://doi.org/10.9770/szv.2021.1(1)

For citation: Ivanovs A. (2021) The impact of metahistory on ethnic identity: the case of the Latvian diaspora in the Soviet Union in the 1920s-1930s. Sociālo Zinātņu Vēstnesis / Social Sciences Bulletin, 32(1): 7-24. https://doi.org/10.9770/szv.2021.1(1)

Citēšanai: Ivanovs A. (2021) Metavēstures ietekme uz etnisko identitāti: latviešu diasporas piemērs Padomju Savienībā 1920.-1930. gados. Sociālo Zinātņu Vēstnesis, 32(1): 7-24. https://doi.org/10.9770/szv.2021.1(1)

Diverse factors influence the processes of shaping, preservation, and development of ethnic identity. Some of these factors have been underestimated by scholars, for instance, the role of common (collective) notions of the past and patterns of metahistory on the whole, which either directly or indirectly influence national consciousness and, consequently, ethnic identity as such. This paper presents a retrospective case study of the potential impact of metahistory patterns on ethnic identity of the Latvians who after the World War I and proclamation of the independent Republic of Latvia remained in the Soviet Union, thus forming the stable and rather numerous Latvian diaspora there. The paper is actually a theoretical research, since there is no possibility to conduct a field study anymore in order to answer the principal question: what factors did support the ethnic identity in the Latvian diaspora in the 1920s-1930s. However, the absence of the empirical data might be to a certain extent compensated by logical reasoning and extrapolation of the data related to the further periods of implementation of the Soviet ethnic policy. The hypothesis put forward by the author of this paper is as follows: during the interwar period for the representatives of the Latvian diaspora in the Soviet Union, metahistory had become one of the principle influential factors that performed dual function. On the one hand, metahistory patterns were intentionally aimed at weakening, deterioration, and even elimination of the ethnic identity in order to replace it with the so-called "proletarian classconsciousness". Meanwhile, the same metahistory patterns paradoxically supported not only the ethnic identity of the Latvians, but also their national (civic) consciousness. The findings of the research allow concluding that the reasons of the actual failure of the Soviet model of meta- 
history in the applied field were as follows: 1) the metahistory pattern was not developed to the full; 2) the essence of the pattern revealed its genetic relationship not with history, but with Marxist sociology, therefore, this pattern could not perform the functions that are immanent just for historical discourse; 3 ) some historic events that formed the core of the metahistory pattern had inevitably raised strong patriotic sentiments in Latvians, thus forming a specific support factor for their ethnic identity. The paper has been prepared within the Project (VPPIZM-2018/1-0018) "Interaction between the Individual, the Society and the State in Process of the History of Latvia: Conflicting Values and Formation of Shared Values during Historical Turning Points" under the National Research Programme "Latvian Heritage and Future Challenges for the Country's Sustainability".

Key words: ethnic identity, support factor, Latvians, diaspora, Soviet Union, interwar period, national consciousness, metahistory, historiography.

Metavēstures ietekme uz etnisko identitāti: latviešu diasporas piemērs Padomju Savienībā 1920.-1930. gados

Dažādi faktori ietekmē etniskās identitātes veidošanās, saglabāšanas un attīstības procesus. Dažiem no šiem faktoriem netiek veltīta pietiekama zinātnieku uzmanība, piemēram, nacionālo apziṇu un, attiecīgi, arī etnisko identitāti kā tādu tieši un netieši ietekmējušiem kopīgiem (kolektīviem) priekšstatiem par pagātni un metavēstures modeḷiem kopumā. Šis raksts piedāvā retrospektīvu situatīvo pētījumu, lai noskaidrotu metavēstures modeḷu potenciālu ietekmi uz latviešu, kuri pēc Pirmā pasaules kara un neatkarīgās Latvijas Republikas dibināšanas palika Padomju Savienībā un izveidoja tur diezgan stabilu un skaitliski lielu diasporu, etnisko identitāti. Būtībā šis raksts tuvojas teorētiskajam pētījumam, jo vairs nav iespēju veikt lauku pētījumus, lai sniegtu atbildi uz principiāli svarīgu jautājumu, kādi faktori īstenībā atbalstīja etnisko identitāti latviešu diasporā 1920.-1930. gados. Tajā pašā laikā empīrisku datu zināmu nepietiekamību daḷēji kompensē log̣iski secinājumi, analizējot pieejamo materiālu, kā arī datu, kas attiecas uz turpmākajiem posmiem padomju etniskās politikas īstenošanā, ekstrapolācija uz pētāmo posmu. Raksta autora izvirzītā hipotēze ir šāda: Padomju Savienībā starpkaru posmā latviešu diasporas pārstāvjiem metavēsture kḷuva par vienu no svarīgākajiem ietekmējošajiem faktoriem, kas veica divējādu funkciju. No vienas puses, metavēstures model̦i tika apzināti orientēti uz etniskās identitātes vājināšanu, izkropḷošanu un pat likvidāciju, lai to aizvietotu ar tā saukto "proletārisko šķiras apziņu”. No otras puses, tie paši metavēstures model̦i paradoksāli atbalstīja ne tikai latviešu etnisko identitāti, bet arī nacionālo (pilsonisko) apziņu. Pētījuma rezultāti dod pamatu secinājumam, ka metavēstures padomju modeḷa faktiskās neveiksmes cēloṇi, veicot tam paredzētās funkcijas, bija šādi: 1) metavēstures modelis kā tāds netika pilnīgi izveidots; 2) šā modeḷa iedaba liecināja par tā ǵenētisko saikni nevis ar vēsturi, bet ar marksistisko sociolog̣iju, tāpēc šis modelis nevarēja sekmīgi veikt vēstures diskursam raksturīgās funkcijas; 3) daži vēsturiski notikumi, kuri veidoja metavēstures model̦a kodolu, neizbēgami izraisīja latviešos spēcīgas patriotiskās jūtas, tādējādi veidojot specifisku etnisko identitāti atbalstošu faktoru. Raksts sagatavots valsts pētījumu programmas "Latvijas mantojums un nākotnes izaicinājumi valsts ilgtspējai” projektā VPP-IZM-2018/1-0018 “Indivīda, sabiedrības un valsts mijiedarbïba kopējā Latvijas vēstures procesā: vērtîbu konflikti un kopīgu vērtību veidošanās vēsturiskos lūzumu posmos".

Atslēgas vārdi: etniskā identitāte, atbalsta faktors, latvieši, diaspora, Padomju Savienība, starpkaru posms, nacionālā pašapziņa, metavēsture, historiogrāfija. 


\section{Влияние метаистории на этническую идентичность: на примере латышской диаспоры в Советском Союзе в 1920-х-1930-х годах}

Различные факторы оказывают влияние на формирование, сохранение и развитие этнической идентичности. Некоторые из них явно недооцениваются учёными - например, роль общих (коллективных) представлений о прошлом и моделей метаистории в целом, которые прямо или косвенно воздействуют на национальное самосознание и, соответственно, на этническую идентичность как таковую. Настоящая статья является ретроспективным ситуационным исследованием потенциального воздействия моделей метаистории на этническую идентичность латышей, которые после первой мировой войны и провозглашения независимой Латвийской Республики остались в Советском Союзе, сформировав там довольно стабильную и многочисленную диаспору. В сущности, статья является теоретическим исследованием, поскольку нет возможности провести полевое исследование с целью ответа на принципиально важный вопрос: какие факторы действительно поддерживали этническую идентичность представителей латышской диаспоры в 1920-е-1930-е годы? В определённой степени недостаточность эмпирических данных может быть компенсирована логическими умозаключениями и анализом имеющегося материала, а также экстраполяцией на ситуацию изучаемого периода более поздних данных о советской национальной политике. Автор выдвигает следующую гипотезу: в межвоенный период для представителей латышской диаспоры в Советском Союзе метаистория стала важным фактором, который выполнял двойственную функцию. С одной стороны, модели метаистории были намеренно нацелены на ослабление, искажение и даже ликвидацию этнической идентичности, чтобы заместить её так называемым «пролетарским классовым сознанием». С другой стороны, те же самые модели метаистории парадоксально поддерживали не только этническую идентичность латышей, но и их национальное (гражданское) сознание. Результаты исследования позволяют выделить основные причины неудачи советской модели метаистории в прикладной сфере (в плане выполнения предписанных функций): 1) модель метаистории так и не была разработана до конца; 2) природа этой модели указывала на её генетическую связь не с историей, а с марксистской социологией, поэтому модель и не могла успешно выполнять функции, естественные для исторического дискурса; 3) некоторые исторические события, входящие в ядро метаисторической модели, неизбежно вызывали у латышей сильные патриотические чувства, тем самым формируя специфический фактор поддержки этнической идентичности. Статья подготовлена в рамках государственной программы исследований «Наследие Латвии и будущие вызовы устойчивому развитию государства», проект VPP-IZM-2018/1-0018 «Взаимодействие индивида, общества и государства в общем историческом процессе Латвии: ценностные конфликты и формирование общих ценностей в переломные исторические этапы».

Ключевые слова: этническая идентичность, фактор поддержки, латыши, диаспора, Советский Союз, межвоенный период, национальное самосознание, метаистория, историография.

\section{Introduction}

It is generally considered that diverse factors have an impact on the processes of shaping, preservation, and development of ethnic identity. Among these factors, modern researchers usually mention social environment, patterns of social behavior, the role of parents, hostility towards the representatives of a definite ethnic group, traditions, religion, language, education/ socialization, cultural awareness, and many more (see, e.g., Bernal, Knight 1993; Nagel 1994; Phinney 1996; Quintana 2007; Shu, Tram 2021; Syed, Azmitia 2008; Walton, Cohen 2007; etc.). However, it seems that the 
potential impact of some factors has been underestimated or even ignored by scholars, for instance, the role of common (collective) notions of the past and patterns of metahistory on the whole, which sometimes directly and sometimes indirectly influence national consciousness and, consequently, ethnic identity as such.

This paper presents a retrospective case study of the potential impact of metahistory patterns on ethnic identity of the Latvians who after the World War I, proclamation of the independent Republic of Latvia on November 18, 1918, and Civil War in the former Russian Empire remained in Soviet Russia, Belarus, and Ukraine, since 1922 - in the Soviet Union, thus forming the stable and rather numerous Latvian diaspora there.

The Latvian expatriate community in the Soviet Union was composed of different groups of diverse social and cultural background: 1) the rural colonists who migrated to the "inner" provinces of the Russian Empire since the $19^{\text {th }}$ century (for more details see Broliss 2000; Kikuts 2015; Skilters 1935); 2) the refugees mostly from Courland (in Latvian - Kurzeme) and Latvian part of Livonia (in Latvian - Vidzeme) who fled to Russia during the World War I (see Latviesu beglu apgadasanas centralkomiteja 1931; Bartele, Salda 2002; Salda 2005); 3) the so-called "red riflemen", social democrats and communists, active supporters of the Bolshevist power and their family members (Ezergailis 1983; Berzins 1995; Bartele 2001; etc.); and other groups of ethnic Latvians such as graduates of the higher educational establishments in Moscow and Saint Petersburg/Petrograd (Salda 2002). It should be noted that the Latvian diaspora in the Soviet Union has been studied in rather many research works - both monographs and papers published in collections of articles and scholarly journals. The first publications appeared in the early 1970s in Latvia under the Soviet rule (Viksna 1970, 1972); however, in focus, there were the activities of the members and organizations affiliated with the Communist Party of Latvia which worked in exile in the USSR. Since 1991, when Latvia has restored de facto its independence, the researchers pay more attention to the problems of the Latvian diaspora in the Soviet Union on the whole (e.g., Salda 2010); more often than not, these problems are studied within the context of diaspora studies on the global scale. ${ }^{1}$

All in all, the Latvian diaspora in the Soviet Union in the interwar period provides rather a solid empirical basis for an in-depth research into the problems of, on the one hand, preservation and, on the other hand, weakening of the ethnic identity within a small group, which represents an expatriate community that exists in hostile environment. It is clear that the ethnic identity of the Latvians in the Soviet Union had been preserved despite the massive, deliberate, and targeted influence of the Soviet (Marxist) ideology, strong pressure exerted by the Communist Party of the Soviet Union (Bolsheviks) and state apparatus, and detachment, even isolation, of the Latvian expatriates from Latvia and the Latvian nation.

This paper is actually a theoretical research, since there is no possibility to conduct a field study anymore, including surveys and focused interviews, in order to answer the principal question: what factors did support the ethnic identity in the Latvian

\footnotetext{
${ }^{1}$ In this connection, the studies currently being conducted and/or supervised by Diaspora and Migration Research Center at the University of Latvia can be mentioned; see: https://www. diaspora.lu.lv/petijumi/ (accessed on 24.06.2021).
} 
diaspora in the 1920s-1930s? The hypothesis put forward by the author of this paper is as follows: during the interwar period for the representatives of the Latvian diaspora in the Soviet Union, metahistory had become one of the principle influential factors that performed dual function. On the one hand, metahistory patterns were intentionally aimed at weakening, deterioration, and - finally - elimination of the ethnic identity in order to replace it with the so-called "proletarian class-consciousness". Meanwhile, the same metahistory patterns paradoxically supported not only the ethnic identity of the Latvians, but also their national consciousness. This interplay between these consequences while applying the metahistory patterns is in the focus of the study.

\section{Theoretical frameworks and historiographic remarks (state-of-the-art of conducted research)}

Most of the concepts used in this paper have emerged in the field of historiographic research. It is universally recognized that historiographic research is an integral part of history studies. Nevertheless, the principal findings and results obtained in the course of a historiographic study might and should be used or, at least, considered while conducting a broad-scale sociological, ethnological, and anthropological research. In this connection, there should be noted that historiography cannot be reduced to professional scholarly research focused on the history of historical research. Historiography also studies the processes of genesis, acquisition, and transformation of the knowledge of the past within definite social groups or society at large. Respectively, meticulous attention is paid to collective representations and notions of the past, as well as to historical myths and stereotypes spread in the society. These aspects of historiography have been studied by the author of the paper in a number of works (see, e.g., Ivanovs 2009a, 2009b, 2013). Summarizing the principal findings, it can be argued that historiography embraces three levels thus forming a hierarchical system. The upper level in this system embraces the research conducted by professionals, which is represented in scholarly papers, monographs, and dissertations. The intermediate level consists of popular works and essays by journalists, writers, litterateurs, and nonprofessional historians who study mainly local history. This level performs a very important function transmitting the knowledge acquired by professional historians to the "popular" level, i.e. to the final target audience of historical research - the society: just in popular works and essays, professional historical discourse is adapted for common people (Shmidt 1997). The third, lower, level represents popular notions, historical myths and stereotypes, common evaluations of the recent past, family stories and legends, biased ideas and preconceptions, and other arbitrary interpretations of historical past. All the aforementioned popular notions are, sometimes, borrowed from the second level or, sometimes, independently generated by definite social/ethnic groups and the society on the whole. ${ }^{2}$

${ }^{2}$ This theoretical discourse is the author's interpretation of the basic approaches to historiography substantiated by B. Croce a century ago (see: Croce 1921; comp. with: Becker 1960). 
Many factors influence all these three levels, and the strongest impact have political institutions and state bodies, which often use history as a specific tool to achieve political and ideological goals. The researchers conclude that sometimes (more often than not) politicization of historical discourse is inevitable, since some problems under investigation cannot be politically or ideologically neutral; moreover, social status, professional society, public opinion, etc. have a definite impact on the mode of representation of the past (Prost 1996). In totalitarian and authoritarian regimes, political elites are convinced that those, who assume control of the past, establish control over the present, too; those, who take control of the time, can also exert control over the people (Ito 1989). That is why elites employ historiography - simultaneously all three levels - to create certain historical myths, evaluation patterns that are aimed to link the past and the present, and social stereotypes; in many cases, these manipulations result in falsifications of the past, but historical research openly serves state bodies and official ideology (Afanas'ev 1996). These problems have been systematically studied by the author of this paper in a number of publications devoted to historical research in Latvia under the Soviet rule, Sovietization of Latvian historiography, and the impact of historiography on ethnic consciousness (e.g., Ivanovs 2003a, 2003b, 2005).

The research conducted by the author testifies that historiography directly deals with basic common notions, which are closely connected with historical consciousness, which is a very important component of the national consciousness, on the one hand, and a structure-forming component of ethnic identity.

In various works published by the author of this paper, the role of historiography, i.e. generalized, scholarly substantiated, and systematized historical notions and reconstructed aspects of the past, in shaping and preserving the ethnic identity has been studied in detail. In the focus of attention, there was the historiographic representation of the history of Latgale - the region located in the Eastern part of present-day Latvia (Ivanovs 2009a, 2009b, 2013).

The principle findings of the conducted in-depth research allowed formulating the basic pattern that describes the relations between historiography and ethnic identity: the studies of the history of Latgale made since the 19th century within the frameworks of different national - Latvian, Russian, Polish, etc. - schools in history studies directly correlate with the basic values, interests, traditions, and historical heritage of the respective ethnic groups that form the ethnic composition of the region. At the same time, each school one way or another emphasizes regional and ethnic identity of the population, thus, "conserving" this identity, insuring its transmission from generation to generation. It should be also noted that the apt theoretical approach to the research into the social functions of historiography relevant to the purposes of this paper was substantiated already in the so-called Soviet Studies. In the collective monograph "Nationality Group Survival in Multi-Ethnic States" published in 1977, there was substantiated a well-balanced logical system of argumentation in order to explain the survival of ethnic identity in the Baltic region despite the attempts of the authorities and ideological institutions to weaken it. The central place in the system was attached to the so-called "support factors" that contributed to the preservation of the basic components of the ethnic identity (Allworth 1977). K. Nyirady, one of the contributors of the volume, on the basis of vast historiographic material proposed a thesis that 
historical research conducted in the Baltic region under the Soviet rule should be treated, on the one hand, as an instrument of ideological control over the Latvians, Lithuanians, and Estonians, and, on the other hand, as a factor that supported their ethnic identity: "Soviet Estonian, Latvian, and Lithuanian historians are responding significantly to what they perceive is theirs nationalities' current status. Their tendency seems evident both through their selection and [...] interpretation of historical topics. As Baltic society continues to modernize, changing emphasis occurs among the various factors that serve as nationality supports. This movement has given historians changing roles to play as active supporters of Baltic culture [...] [T] he historical interests of a nationality could be considered part of the objective identity factor of cultural maintenance. An increase in emphasis upon this factor may result in the growth of a component of the regulatory factor of group pride [...]" (Nyirady 1977: 58).

As shown further in the paper, the concept "support factor" is quite relevant to the research into the role of historiographic patterns - metahistory - in preservation and in transformation (to a certain extent) of the ethnic identity of the members of the Latvian diaspora in the Soviet Union in the interwar period; therefore, this concept is widely used both directly and indirectly in the paper.

To make this study methodologically more precise, the author of the paper has recently revised the basic conceptual frameworks that form the theoretical basis of the research introducing the concept of "metahistory" (see Ivanovs 2019).

It should be considered that the reconstructed image of the past provided by historiography only in general lines corresponds with the "real" past. In its turn, the knowledge of the society about the past encompasses these rough images - approximate outlines of the real events, arbitrary evaluations, and conceptualizations that are shaped to meet present-day social expectations, political requirements, and generally accepted stereotypes. These reconstructions and conceptualizations actually perform the metahistory function, since they are used to describe, explain, and evaluate the past within the current (nowadays) perspective. Thus, metahistory is a specific tool aimed at public consciousness. Such an interpretation of the concept of metahistory is to be considered as the further development of concept initially substantiated by H. White (White 1973). In contrast to $\mathrm{H}$. White, the author of the paper does not reduce the concept of metahistory to stylistic and linguistic features of historiographic discourse (narrative), because the principal importance should be attached to the completeness of the image of the past, priorities in historiographic representations, the mode of substantiation of principal theses, role of conjuncture and political intention in history writing, etc.

Thus, the concept of metahistory actually replaces both the concept of historiographic representation and the concept of historical reconstruction (i.e., historiography). However, these concepts are not quite identical. The concept "historiography" emphasizes, first and foremost, the historical discourse as such in close connection with the development of historical research and history knowledge. In its turn, the concept "metahistory" deals with the integral image of the past that exists both in historical works and in common public notions of the past. Consequently, the concept of metahistory "migrates" from professional historical research to public/social consciousness, thus transforming into a specific social phenomenon. 


\section{Empirical basis of the research}

The empirical basis of this research encompasses the editions - mainly books and, to a lesser extent, periodicals - that either way touch aspects of the past, deal with historical facts, and provide overall or fragmentary insight into historical process. These editions were published in the Latvian language in Soviet Russia, Belarus, and Ukraine in the 1920s-1930s; some few publications were prepared also in the Latgalian language. The target audience of these editions, which on the whole provide a wellconstructed and simultaneously rather fragmentary image of the past, were Latvians, who in the interwar period lived in the Soviet Union and represented different, actually entirely all, social and professional groups - Communist party functionaries, state officials, intelligentsia, workers, and peasants. It allows concluding that the range of the potential impact of the editions overlapped the whole expatriate Latvian community in the USSR.

The scope of publications and the activities of the publishing houses and state institutions involved in preparation of these editions is a topic of a special in-depth research. To a certain extent, the overall view of the problem can provide research papers and chapters in the monographs by Latvian scholars (e.g., Birons, Dorosenko 1966; Karulis 1967; Biron A., Biron M. 1981). During the Soviet rule, the exclusive attention was paid to the publishing houses affiliated with the Latvian Communist Party (Toman 1983), as well as to some "iconic" publications on the history of the Latvian Social Democracy and Communist Party, "class struggle", and other ideologically biased topics (Biron M., Biron A. 1971, 1972). Since the restoration of the independence of Latvia, the authors of research papers try to provide a well-balanced insight into the history of Latvian book publishing in the Soviet Union (Salda 2010; Zanders 2021; Ivanovs 2021).

In the thematic frameworks of this paper, there should be mentioned that all the editions represent the Soviet/Marxist ideological patterns; however, the density of ideological phraseology and dogmatic cliché varies within rather broad limits in the publications issued by different publishing houses and state bodies; the purposes of definite editions - e.g., propaganda, education and self-education, informing, entertainment and relaxation, publicizing of research findings (quite rare purpose), etc. - should also be taken into consideration. Thus, mainly propagandistic editions were issued by the publishing house "Spartaks" (1920-1936) affiliated with the Foreign Bureau of the Central Committee of the Latvian Communist Party; meanwhile, the range and nomenclature of the publications prepared by the publishing house "Prometejs" (19231937) was much wider and encompassed social and political editions, publications of historical sources and historical essays, textbooks, and even belletristic literature (see in detail: Izglitibas biedriba "Prometejs" 1933; Salda 2010: 331-344). Among Latvian publishers there should be also mentioned the publishing house "Strēlnieks" ("Rifleman", 1921-1923), after reorganization - "Latvju izdevnieciba" "Latvian Publishing House", 1923-1928), that focused mainly on belletristic literature including poetry, drama, novels, and other works devoted to "class struggle", "revolutionary movement", and "building of Socialism". As a result of the "Great Purge", in 1937-1938, 
the specialized Latvian publishing houses in the Soviet Union were liquidated; and further not numerous editions in Latvian were published for agitation and education purposes by Soviet state and party institutions only.

One more notable trend in the publishing activities of the Latvian diaspora in the Soviet Union in the interwar period can be pointed out: despite the impact of the Marxist/Soviet ideology, the variety of ideas and patterns in the representation of the past was relatively wide in the late 1910s - early 1920s until the Soviet regime had assumed the total control over ideological sphere; later on the diversity was remarkably diminished; at last, in the late 1930s, when the infamous "Short Course on Party History" was published (Maslov 1966), the metahistory pattern closely linked with the Soviet ideology was transformed into dogma.

\section{Findings: the main patterns in the representation of the Latvian past in editions issued by Latvian diaspora}

At first glance, the image of the Latvian past (re)constructed in the aforementioned editions is fragmented. Supposedly, this might have lessened the potential impact of the unsystematic metahistory pattern represented in scattered publications on the ethnic identity of the Latvians in the USSR. This fragmentation was inevitable, taking into consideration the overall status of historical research and the situation with dissemination of historical knowledge in the 1920s - early 1930s. In 1923, shortly after the Bolshevist takeover, history was totally removed from study programs (Shchulepnikova 2014): it is quite obvious that the leaders of the Soviet state understood well that history knowledge results in undesirable for Soviet ideology consequences such as critical thinking, intellectual independence, patriotism, ability to evaluate not only past but also contemporary events, etc. That is why there was made an attempt to replace history with ideologically biased, schematic social studies closely linked to Marxist dogmas. Moreover, both on empirical and conceptual levels, it was impossible to replace immediately the existing models of history representation with the new ones shaped on the bases of Marxism. Within these attempts, the political campaign against Russian historians and historical research as such was launched in the late 1920s (Shmidt 1996). Only in 1932, history returned to study programs.

Despite the efforts to replace traditional representation of history with the sociologicized Marxist scheme that minimally correlates with historical reality, some extremely important "node points" in the history of the Latvians were always in the focus of attention of Soviet ideological institutions, Communist party functionaries, and propagandists, as well as publicists and writers who one way or another contributed to the creation of the metahistory pattern. Just these "node points" drew the outlines of the metahistory pattern - image of the Latvian past - aimed to weaken historical consciousness of the representatives of Latvian diaspora.

It is quite natural that within the emerging metahistory pattern a special emphasis was put on the so-called "revolutionary movement" and the participation of the ethnic Latvians in it. Judging by the number of publications that up to now preserve their 
significance for scholarly research, one of the most important aspects of this revolutionary history was the Revolution of 1905 - the turning point in the development of the Latvian national (civic) consciousness and genesis of the Latvian nation (see relevant research papers and monographs characterized in Ivanovs 2006). Among publications on this topic, first of all there should be mentioned collections of primary historical sources - documentary (archival) records (not numerous), life stories and testimonies by revolutionaries, articles from newspapers issued in 1905-1906, photos and sketches, leaflets and proclamations, etc. (see, e.g., LKP Vestures komisija 1925; Endrups, Feldmanis 1933; Lencmanis 1936). Since the early 1920s, there were regularly published memoirs written by the participants of the revolutionary movement (e.g., Landers 1925; Straujans 1935; Beika 1937); belletristic literature on this topic was also issued frequently. Paradoxically, within the scope of editions about the Revolution of 1905, only some few popular (mainly propagandistic) works can be mentioned (OzolsPriednieks 1927; Stucka 1926). Moreover, not a single research paper or monograph on this topic was published in the Soviet Union in the interwar period. It is safe to assume that the Soviet authorities and Communist party functionaries well comprehended the dual essence of the revolutionary events in the Baltic provinces: on the one hand, this Revolution was an outstanding manifestation of the "class struggle", thus, fully corresponding with the outlines of the emerging metahistory pattern based on the Marxist dogma. On the other hand, even more striking there were manifestations of the national liberation movement in the course of the revolutionary struggle often aimed against Baltic Germans. It was also quite understandable that just in the course of these events the prerequisites for the establishment of the independent Republic of Latvia emerged. Furthermore, the events related to the Revolution, especially to its suppression, produced extremely strong emotional impact on every ethnic Latvian (see the collection of visual historical sources: 1905. gada revolücija 1926).

Thus, the designers of the metahistory pattern met a hard challenge: it was impossible to conceal this momentous event in the history of the Latvian nation, since there were still many participants of it alive both in Latvia and in the USSR; at the same time this event should not be overemphasized in order not to question the integrity of the metahistory pattern as such. That is why, even in the source publications devoted to the Revolution of 1905 , the image of this historic event was thoroughly constructed and, to a certain extent, falsified: the editors of the publications tried to correlate directly the events in the Baltic provinces and the inner provinces of the Russian empire; documentary historical sources did not took the central place in the publications instead of them there were usually published "testimonies" of the participants, most of whom were Soviet state and party functionaries; the collections of the sources were supplemented with the fragments from the works by Lenin and other Soviet leaders that brought desirable light on the revolutionary events, etc. Nevertheless, it can be argued that despite these efforts, any commemoration or remembrance of the Revolution of 1905 inevitably contributed to national awareness and civic consciousness, especially in long-term perspective, thus supporting ethnic identity of the Latvians.

In order to compensate this bias within the metahistory pattern designed for the representatives of the Latvian diaspora (but, in perspective, also for the Latvians in 
Latvia), other revolutionary events were put forward, first and foremost the so-called “Great October Socialist Revolution” (Viksne 1918; Danisevskis 1918-1920; Stalins 1937 , etc.), as well as other manifestations of "class struggle" against the political reaction of the tsarist regime, "bourgeois" Republic of Latvia (in the Soviet discourse "White Latvia"), Western intervention, local "exploiters" - bourgeoisie and landlords in the years of the Civil War, etc. (Strauss 1931; Endrups, Feldmanis 1936) Rather meticulous attention was paid to the so-called "red riflemen" - ethnic Latvians who within riflemen units actively participated in the Bolshevist takeover in 1917, Civil War, and other events in the inner provinces of the former empire (Apins 1934-1935). As in the case of representation of the events of the Revolution of 1905, the historical narrative was focused mainly on social conflict thus diminishing or, sometimes, entirely eliminating the aspects of national movement and ethnic conflict. No doubt, it was done intentionally in order to replace national (civic) consciousness with "class consciousness" linked with "proletarian internationalism". In this case, it is difficult to conclude whether this attempt was successful, and if it was successful - to what extent. Presumably, these efforts also might have had a dual impact on Latvians, because many of the stereotypes and cliché used to describe the "class enemies" and "White Latvia" were too rough, conjunctural, and even fictious, but the narratives often transformed into propagandistic essays (Berzins-Andersons 1923; Lejins 1930; Krumins 1935, etc.). At the same time, some real, unbiased testimonies and memoirs might have had a direct impact on ethnic sentiments; unfortunately such publications appeared very seldom (see, e.g., autobiographic novel that has some memoir features: Rihters 1936; see also memoirs about the World War I: Kirss 1930).

In the publications on recent history, the most popular topic was the activities of the Latvian Social Democracy and, since 1919, Latvian Communist Party, as well as the role of the Communist Party of Russia (Bolsheviks) and, since 1925, the Communist Party of the Soviet Union (Bolsheviks). Among documentary editions, there totally dominated official publications; the preparation of these collections of documents was thoroughly supervised either by the Communist Party or by organizations affiliated with it, for instance, the Historical Commission of the Latvian Communist Party (LKP Vestures komisija 1924, 1929, 1935). The same can be said about popular essays on the history of the Communist Party of the Soviet Union (Bolsheviks) translated from Russian into Latvian (e.g., Popovs 1928). The official status of these editions and their use mostly for the indoctrination of the representatives of the Latvian diaspora by the structures of the infamous Glavpolitprosvet (the Main Political and Educational Committee of the People's Commissariat of Education, 1920-1930) as well as in the advance training courses for party and Soviet functionaries dramatically reduced the sphere of circulation of such books. One can hardly imagine that these editions were read for self-education or relaxation purposes. Therefore, the impact of these editions on the ethnic identity of the Latvians presumably was minimal; nevertheless, the essays and documentary editions about the history of the Communist Party played a very important role in the process of shaping and development of the metahistory pattern: they served as stable templates for elaboration of other historical narratives devoted to all other aspects of the modern history of Latvia and the Soviet Union on the whole. 
It should be added that the template was finally formulated in the aforementioned "Short Course on Party History", which was published in Russian in 1938 and in translation into Latvian in 1941 (see TsK VKP(b) 1938; VK(b)P CK 1941). Since that time any deviations from the officially authorized interpretations of modern history were absolutely impossible.

In contrast to the history of "class struggle" and, to a lesser extent, the history of "building of socialism/communism" (e.g., Jokums 1933), all other aspects of the modern history of Latvia and the Soviet Union at large were underrepresented in the metahistory pattern. There can be mentioned only some arbitrary aspects of the history of Latvia that were highlighted in the works - mostly popular essays - published in the USSR during the interwar period, for instance, Russification policies in Latvia in the 19th century (Preiss 1932), the emergence and development of Latvian colonies in Belarus (Skilters 1935), ethnic/nationality problem in Latgale region (Skilters 1934), and some other topics. It seems that such works did not play any noticeable role within the emerging metahistory pattern and rather reflected particular interests of their authors. The same can be said about some few publications that embrace wide range of historical aspects, such as the history of ideologies in Latvia (Klusais 1925) or the generalizing essay on the history of Latvia until the end of the 18th century (Landers 1922). These essays were published in the first half of the 1920s when the new metahistory pattern was not stable enough.

It is obvious that chronologically the metahistory pattern was constructed within the narrow limits, i.e. since the middle - end of the 19th century till the beginning of the 1920s. All other periods were actually ignored. Moreover, it can be argued that the metahistory pattern was separated from the World history on the whole: during the interwar period, there were published only some few popular propagandistic essays about revolutionaries and "class struggle" abroad (e.g., Ozols-Priednieks 1926). At the same time, the metahistory pattern that replaced the real history of Latvia closely linked it with (and even merged it into) the history of the Soviet Union. All in all, the metahistory pattern was very schematic and paradoxically unhistorical, since it neglected the historical experience and almost all mankind values correlated with this experience.

In order to make this metahistory model effective and to ensure its real impact on the consciousness of the ethnic Latvians it was adapted to the level of knowledge and perception of ordinary people - workers, peasants, and white-collars that formed the majority in the Latvian diaspora. Accordingly, the basic theses related to the metahistory pattern were widely popularized and explained in numerous articles in the press and brochures that contributed to further vulgarization of the promoted metahistory pattern. These publications were entirely propagandistic; many of them were published in serial editions of the publishing house "Spartaks" such as "Library of a Propagandist”, “Worker's Travel Bag”, "Communist Voter's Travel Bag”, etc.

Special and rather intensive efforts were made to impose the new metahistory pattern by means of education and self education. Starting with the primary school, in education of young Latvians there were used ideologically biased textbooks and even ABC books (Krukle 1930). However, just in the course of education of adults 
ideological pressure was extremely high. In this connection, there can be mentioned the so-called Likbez - the campaign of eradication of illiteracy (1920-1930) and ideologically biased textbooks simultaneously used both for education and indoctrination of the adults (Mizze 1928; Jakobsons 1929). For more advanced, i.e. educated, adults, there were published tutorials on the basics of Leninism (Olhovijs 1930; Stalins 1935) and textbooks on the so-called "historical materialism" written by the Soviet leaders (Stucka 1920; Buharins 1923; Stalins 1939). These textbooks were used in advanced training courses and higher educational establishments. Apparently, the aim of such editions was to replace history with a vulgar sociological scheme.

At last, one of the most influential "tools" used to impose the metahistory pattern was belletristic literature, namely, novels, stories, dramatic works, and poetry devoted to revolutionary movement and "building of socialism". Some titles vividly speak for themselves: "Rally Speeches: Contemporary Rhythms" (Eiduks 1926), "Riflemen and Grenades/Shells" (Jokums 1936), and the like. Such works were widely published in the Soviet Union.

\section{Conclusion: concerning potential and real impact of the constructed image of the past on ethnic identity}

As noted above in this paper, it is hardly possible to reveal the real impact of the thoroughly constructed metahistory pattern on the consciousness and, hence, on the ethnic identity of the Latvians in the Soviet Union during the interwar period. However, the absence of the empirical data might be to a certain extent compensated by logical reasoning and extrapolation of the data related to the further periods of implementation of the Soviet ethnic (nationality) policy. Already in the 1960s - 1970s, the researchers in the West have concluded (Tillett 1969; Mazour 1971; Allworth 1977) that massive efforts to weaken identity of the ethnic groups by means of historical data manipulations were not very effective, and sometimes these efforts even resulted in strengthening of the national (civic) consciousness and ethnic identity. Very likely the same effect was achieved while imposing the Soviet ideologically biased metahistory model during the interwar period. Anyway, ethnic Latvians who lived un the Soviet Union in the 1920s - 1930s did preserve their ethnic identity.

The reasons of the actual failure (in the applied field, of course) of the Soviet model of metahistory were as follows: 1) the metahistory pattern was not developed to the full - many aspects and key nodes were very schematic and even contradictory; 2) the essence of the pattern revealed its genetic relationship not with history, but with Marxist sociology - therefore, this pattern could not perform the functions that are immanent just for historical discourse; 3 ) some historic events that formed the core of the metahistory pattern had inevitably raised strong patriotic sentiments in Latvians, thus forming a specific support factor for their ethnic identity. 


\section{References}

Afanas'ev Iu. (1996) Fenomen sovetskoi istoriografii. Afanas'ev Iu. (Ed.) Sovetskaia istoriografiia. Moskva: Rossiiskii gosudarstvennyi gumanitarnyi universitet, pp. 7-41. (In Russian) Allworth E. (1977) Flexible defenses of a nationality. Allworth E. (Ed.) Nationality Group Survival in Multi-Ethnic States: Shifting Support Patterns in the Soviet Baltic Region. New York, London: Praeger Publishers, pp. 1-23.

Apins R. (Red.) (1934-1935) Latvju revolucionarais strelnieks. Latvju strelnieku vestures komisija. I-II [sej.]. Maskava: Prometejs. (In Latvian)

Bartele T. (2001) Latviesu kreisas organizacijas Maskava padomju varas pirmajos gados (19181922). Latvijas Arhivi, Nr. 1, 61.-77. 1pp. (In Latvian)

Bartele T., Salda V. (2001) Latviesi Maskava, 1915-1922. Daugavpils: Saule. (In Latvian)

Bartele T., Salda V. (2002) Latviesu begli Petrograda (1915-1920). Latvijas Arhivi, 2002, Nr. 1, 83.-99. lpp. (In Latvian)

Becker C. (1960) Everyman His Own Historian. El Paso: Academic Reprints Inc.

Beika D. (1937) Mezabralu gads: Cinas un cilveki Piekta gada revolucija. Memuari. Maskava: Prometejs. (In Latvian)

Bernal M., Knight G. (Eds.) (1993) Ethnic Identity: Formation and Transmission among Hispanics and Other Minorities. Albany (NY): State University of New York Press.

Berzins V. (1995) Latviesu strelnieki: drama un tragedija. Riga: Latvijas Vestures instituta apgads. (In Latvian)

Berzins-Andersons J. (1923) “Demokratiskas” Latvijas valsts pamati un vinas nakotne. Pleskava: Spartaks. (In Latvian)

Biron A., Biron M. (1972) K voprosu o napisanii istorii revoliutsionnogo dvizheniia v Latvii. Izvestiia Akademii nauk Latviiskoi SSR, Nr. 8, s. 20-40. (In Russian)

Biron A., Biron M. (1981) Stanovlenie sovetskoi istoriografii Latvii. 20-e i 30-e gody XX veka. Riga: Zinatne. (In Russian)

Biron M., Biron A. (1971) O podgotovke publikatsii "Kniga pamiati pavshikh bortsov revoliutsii”. Izvestiia Akademii nauk Latviiskoi SSR, Nr. 5, s. 53-69. (In Russian)

Birons A., Dorosenko V. (1966) Vestures zinatnes attistiba Padomju Latvija. Latvijas PSR ZA Vestures instituts. Riga: Zinatne. (In Latvian)

Broliss J. (2000) Latgales latviesu likteni Sibirija no iecelosanas lidz 1938. gadam. Vesturiski filozofiska apcere. Rezekne: Latgales Kulturas centrs. (In Latvian)

Buharins N. (1923) Vesturiska materialisma teorija: populars marksistiskas sociologijas kurss. Maskava: Prometejs. (In Latvian)

Croce B. (1921) Theory and History of Historiography. London: G.C. Harrap.

Danisevskis J. (1918-1920) Socialistiskas revolucijas prieksvakara. 3 sej. Maskava: Spartaks. (In Latvian)

Eiduks J. (1926) Mitinrunas: laikmetiski ritmi. Maskava: Latvju izdevnieciba. (In Latvian)

Endrups R., Feldmanis A. (Sast.) (1933) Revolucionaras cinas krituso pieminas gramata. 1. sej.: 1905. g. revolucija. Maskava: Prometejs. (In Latvian)

Endrups R., Feldmanis A. (Sast.) (1936) Revolucionaras cinas krituso pieminas gramata. 2. sej.: 1907-1917. Maskava: Prometejs. (In Latvian)

Ezergailis A. (1983) The Latvian Impact on the Bolshevik Revolution. Boulder (Col.): Columbia University Press (East European Monographs, No. 144). 
Ito T. (Ed.) (1989) Facing Up to the Past. Soviet Historiography under Perestroika. Sapporo: Slavic Research Center, Hokkaido University.

Ivanovs A. (2003a) Latvijas PSR historiografija (konceptuals parskats). Latvijas Vesture: Jaunie un Jaunakie Laiki, Nr. 2(50), 75.-83. lpp.; Nr. 3(51), 69.-77. lpp. (In Latvian)

Ivanovs A. (2003b) Vestures zinatne ka padomju politikas instruments: historiografijas konceptualais limenis. Padomju okupacijas rezims Baltija 1944.-1959. gada: Politika un tas sekas: Starptautiskas konferences materiali. (Latvijas Vesturnieku komisijas raksti, 9. sejums). Riga: Latvijas vestures instituta apgads, 59.-70. lpp. (In Latvian)

Ivanovs A. (2005) Sovietization of Latvian Historiography 1944-1959: Overview. Caune A. (Ed.) The Hidden and Forbidden History of Latvia under Soviet and Nazi Occupations 19401991: Selected Research of the Commission of the Historians of Latvia (Symposium of the Commission of the Historians of Latvia, Vol. 14). Riga: Institute of the History of Latvia, pp. 256-270.

Ivanovs A. (2006) 1905. gada revolucija Latvija: Historiografisks apskats. Berzins J. (Atb. red.) 1905. gads Latvija: 100. Riga: Latvijas vestures instituta apgads, 73.-111. lpp. (In Latvian)

Ivanovs A. (2008) Historiografija ka regionalas identitates balsts: ieskats Latgales historiografija. Latvijas Vesture: Jaunie un Jaunakie Laiki, Nr. 3(71), 98.-112. 1pp. (In Latvian)

Ivanovs A. (2009a) Historiography of Latgale within the context of political and ethnic history of the region. Acta Humanitarica Universitatis Saulensis. Mokslo darbai, T. 9: Alternation of Cultural Memory and Local History. Šiauliai, pp. 72-86.

Ivanovs A. (2009b) Latgales historiografija ka regionalas identitates "atbalsta faktors”. Kolosova A. (Atb. red.), Medveckis A. (Sast.) Sabiedriba un kultura: Rakstu krajums, XI. Liepaja: LiePA, 34.-41. lpp. (In Latvian)

Ivanovs A. (2013) Historiography as framing and support factor of ethnic identity: The case of historiography of Latgale. Volkovs V., Hanovs D., Runce I. (Eds.) Ethnicity. Towards the Politics of Recognition in Latvia: 1991-2012. Riga: Zinatne, pp. 283-314.

Ivanovs A. (2019) Latvijas historiografija un Latvijas vesture 16.-18. gadsimta: jautajums par "realas" pagatnes aizvietosanu ar metavesturi. Klava V. (Sast.) Latvijas teritorija agrini moderna laikmeta politiskaja dimensija 16.-18. gadsimta. Riga: Latvijas Nacionala biblioteka, 22.39. lpp. (In Latvian)

Ivanovs A. (2021, in print) Vesture latviesu diaspora PSRS starpkaru posma sagatavotajos izdevumos: jautajumam par publikacijas reprezenteta pagatnes tela un nacionalas pasapzinas mijiedarbiba. Zanders V. (Atb. red.) Gramata Latvijai arpus Latvijas. Riga: Latvijas Nacionala biblioteka. (In Latvian)

Izglitibas biedriba "Prometejs". (1933) Par socialistisku kulturu. Izglitibas biedribas "Prometejs” 10 gadu darbs, 1923-1933. Maskava: Prometejs. (In Latvian)

Jakobsons K. (1929) Oktobra balsti. Maskava: SPRS Tautu centrala izdevnieciba. (In Latvian) Jokums K. (1933) No viensetam uz kolektiviem: apcerejums par kolektivizacijas procesiem SPRS latvju kolonijas. Maskava: Prometejs. (In Latvian)

Jokums K. (1936) Strelnieki un granatas. Maskava: Prometejs. (In Latvian)

Karulis K. (1967) Latviesu gramata gadsimtu gaita. Riga: Liesma. (In Latvian)

Kikuts T. (2015) Latviesu zemnieku koloniju izveidosanas Krievijas imperijas Eiropas dala (19. gs. 40. gadi - 1914. gads): Promocijas darbs. Riga: Latvijas Universitate. Available: https://dspace.lu.lv/dspace/handle/7/28212 (accessed on 24.06.2021). (In Latvian)

Kirss J. (1930) Aiz dzelzs zogiem. Imperialistiska kara gustekna piezimes, 1914-1918. Maskava: SPRS Tautu centrala izdevnieciba. (In Latvian) 
Klusais (1925) Piezimes par latviesu ideologijas vesturi. Maskava: Prometejs. (In Latvian) Krukle E. (Sast.) (1930) Oktobrens: Abece majai un skolai. 2. parlab. izd. Maskava: Prometejs. (In Latvian)

Krumins J. (Pilats) (1935) Baltijas valstu neatkariba un hitlerisms. Maskava: Spartaks. (In Latvian)

Landers K. (1922) Latvijas vesture. 1. sej. Maskava: Krievijas Komunistiskas partijas CK Latsekcija. (In Latvian)

Landers K. (1925) 1905. gada prieksvakara. Atminas un raksturojumi. Maskava: Latvju izdevnieciba. (In Latvian)

Latviesu beglu apgadasanas centralkomiteja. (1931) Latviesu beglu apgadasanas centralkomiteja. Riga: Vila Olava fonda sabiedriba. (In Latvian)

Lejins K. (1930) Ka izcelas Latvijas valsts un vai darba laudis var pret to noziegties? Maskava: Spartaks. (In Latvian)

Lencmanis J. (Red.) (1936) 1905. gads. LKP vestures komisija. Maskava: Prometejs. (In Latvian) LKP Vestures komisija (1924) Proletariska revolucija Latvija. L.K.P. vestures materiali. 1. dala: Stradnieku skiras partijas sakotne. Pleskava: Spartaks. (In Latvian)

LKP Vestures komisija (1925) 9. un 13. janvaris: 1905. g. janvara dienas un vinu pecskanas Latvija. Maskava: Spartaks. (In Latvian)

LKP Vestures komisija (1929) L.K.P. 25 gadi: Rakstu un materialu krajums. Kongresu, konferencu un CK svarigakie lemumi un rezolucijas. Maskava: Prometejs. (In Latvian)

LKP Vestures komisija (1935) Latvijas Socialdemokratijas II kongress, Londona, 3.-7. junija 1907. g. Protokoli. Maskava: Prometejs. (In Latvian)

Maslov N. (1966) "Kratkii kurs istorii VKP(b)" - entsiklopediia i ideologiia stalinizma i poststalinizma, 1938-1988 gg. Afanas'ev Iu. (Red.) Sovetskaia istoriografiia. Moskva: Rossiiskii gosudarstvennyi gumanitarnyi universitet, s. 240-273. (In Russian)

Mazour A. (1971) The Writing of History in the Soviet Union. Stanford (Calif.): Hoover Institution Press. (Hoover Institution Publications, 87).

Mizze E. (1928) Oktobra laukos: Darba gramata pieauguso skolam un pasmacibai. Maskava: SPRS Tautu centrala izdevnieciba. (In Latvian)

Nagel J. (1994) Constructing ethnicity: creating and recreating ethnic identity and culture. Social Problems, Vol. 41, pp. 152-176. DOI: https://doi.org/10.1525/sp.1994.41.1.03x0430n

Nyirady K. (1977) Historians and the Nationality Dissatisfaction. Allworth E. (Ed.) Nationality Group Survival in Multi-Ethnic States: Shifting Support Patterns in the Soviet Baltic Region. New York, London: Praeger Publishers, pp. 58-82.

Olhovijs B. (1930) Leninisma abece: Macibu gramata partijas skolam uz laukiem un pasmacibai. Maskava: Prometejs. (In Latvian)

Ozols-Priednieks K. (1926) Revolucionarie svetki. Parizes Komunas pieminas diena. Maskava: Latvju izdevnieciba. (In Latvian)

Ozols-Priednieks K. (1927) Revolucionarie svetki. 9. un 13. janvaris. Maskava: Latvju izdevnieciba. (In Latvian)

Phinney J. (1996) Understanding ethnic diversity: the role of ethnic identity. American Behavioral Scientist, Vol. 40, pp. 143-152. DOI: https://doi.org/10.1177/0002764296040002005

Popovs N. (1928) Vissavienibas Komunistiskas (lielinieku) partijas vestures apskats. Maskava: Prometejs. (In Latvian)

Preiss P. (1932) Latvijas tautskola rusifikacijas laikmeta: populars apcerejums par latvju tautskolas vesturi (1882-1917). Maskava: Prometejs. (In Latvian) 
Prost A. (1996) Douze leçons sur l'histoire. Paris: Seuil. (In French)

Quintana S. (2007) Racial and ethnic identity. Developmental perspectives and research. Journal of Counseling Psychology, Vol. 54, pp. 259-270. DOI: https://doi.org/10.1037/0022-0167. 54.3.259

Rihters O. (1936) Mezi salc. Maskava: Prometejs. (In Latvian)

Salda V. (2002) Latviesi Maskava, 19. gadsimta otra puse - 1914. gads. Daugavpils: Saule. (In Latvian)

Salda V. (2005) Latviesu begli Krievija (1915-1920). Latvijas Arhivi, Nr. 3, 7.-30. lpp. (In Latvian)

Salda V. (2010) Latviesi Maskava, 1923-1938. Daugavpils: Saule. (In Latvian)

Shchulepnikova E. (2014) Pochemu v 1920-e gody v shkolakh ne prepodavali istoriiu. Prepodavanie istorii $v$ shkole. Nauchno-teoreticheskii i metodicheskii zhurnal, Nr. 5, s. 26-29. Available: http://pish.ru/blog/archives/3238 (accessed on 24.06.2021). (In Russian)

Shmidt S. (1996) Sergei Fedorovich Platonov i "Delo Platonova”. Afanas'ev Iu. (Red.) Sovetskaia istoriografiia. Moskva: Rossiiskii gosudarstvennyi gumanitarnyi universitet, s. 215-239. (In Russian)

Shmidt S. (1997) Khudozhestvennaia literatūra i iskusstvo kak istochnik formirovaniia istoricheskikh predstavlenii. Shmidt S. Put' istorika. Izbrannye trudy po istochnikovedeniiu i istoriografii. Moskva: Rossiiskii gosudarstvennyi gumanitarnyi universitet, s. 113-115. (In Russian)

Shu M., Tram J. (2021) The influence of family and community factors on ethnic identity. Journal of Multicultural Counseling and Development, Vol. 49, pp. 32-44. DOI: https://doi.org/ 10.1002/jmcd.12204

Skilters K. (1934) Latgales nacionalais jautajums. Baltkrievijas ZA. Latviesu sektors. Minska: Baltkrievijas Zinatnu akademijas izdevnieciba. (In Latvian)

Skilters K. (1935) Latvju zemnieks Baltkrievija pirms un pec Oktobra revolucijas: Vesturiska monografija. Baltkrievijas Zinatnu akademijas Nacionalmazakumu instituta Latvju sekcija. Minska: Baltkrievijas Zinatnu akademijas izdevnieciba. (In Latvian)

Stalins J. (1935) Leninisma jautajumi. Maskava: Prometejs. (In Latvian)

Stalins J. (1937) Oktobra revolucijas un Krievijas komunistu taktika. Oktobra revolucijas starptautiskais raksturs. Maskava: Arzemju stradnieku izdevniecibas biedriba. (In Latvian)

Stalins J. (1939) Par dialektisko un vesturisko materialismu. Maskava: Literaturas izdevnieciba svesas valodas. (In Latvian)

Straujans J. (1935) Meza brali. Maskava: Prometejs. (In Latvian)

Strauss V. (1931) Padomju Latvija un starptautiska kontrrevolucija. Latvju strelnieku vestures komisija. Maskava: Prometejs. (In Latvian)

Stucka P. (1920) Lekcijas par vesturisko materialismu. Maskava: KKP CK Latviesu agitacijas un propagandas nodala. (In Latvian)

Stucka P. (1926) 1905. gads Latvija. Maskava: Prometejs. (In Latvian)

Syed M., Azmitia M. (2008) A narrative approach to ethnic identity in emerging adulthood. Bringing life to the identity status model. Developmental Psychology, Vol. 44, pp. 1012-1027. DOI: https://doi.org/10.1037/0012-1649.44.4.1012

Tillett L. (1969) The Great Friendship: Soviet Historians on the Non-Russian Nationalities. Chapel Hill: University of North Carolina Press.

Toman B. (1983) Istoriografiia istorii Kommunisticheskoi partii Latvii. (Konets XIX v. nachalo 60-kh godov XX v.). Riga: Avots. (In Russian) 
TsK VKP(b) (1938) Istoriia Vsesoiuznoi Kommunisticheskoi partii (bol'shevikov). Kratkii kurs. Moskva: Gosudarstvennoe izdatel'stvo politicheskoi literatury. (In Russian)

Viksna Dz. (1970) Latyshi v Belorusskoi SSR v 20-30-kh godakh. Izvestiia Akademii nank Latviiskoi SSR, Nr. 12, s. 15-27. (In Russian)

Viksna Dz. (1972) Latviesu kulturas un izglitibas iestades Padomju Savieniba 20.-30. gados. LPSR ZA Vestures instituts. Riga: Zinatne. (In Latvian)

Viksne P. (1918) Oktobra revolucija Latvija. Oktobra revolucijas gada svetkos, 1917-1918. Maskava: Latvijas Socialdemokratijas centralas Komitejas Krievijas birojs, 62.-83. lpp. (In Latvian)

VK(b)P CK (1941) Vissavienibas Komunistiskas (bolseviku) partijas vesture. Isais kurss. Riga: Partijas apgads. (In Latvian)

Walton G., Cohen G. (2007) A question of belonging: race, social fit, and achievement. Journal of Personality and Social Psychology, Vol. 92, pp. 82-96. DOI: https://doi.org/10.1037/00223514.92.1.82

White H. (1973) Metahistory. The Historical Imagination in Nineteenth-Century Europe. Baltimore: Johns Hopkins University Press.

Zanders V. (2021) Gramatnieciba Latvija. Nacionala enciklopedija. Available: https://enciklopedija.lv/skirklis/22533 (accessed on 24.06.2021). (In Latvian) 